\title{
Pigments, dyes, and black enamel-the colorants of reverse paintings on glass
}

\author{
Oliver Hahn • Simone Bretz • Carola Hagnau • \\ Hans-Jörg Ranz • Timo Wolff
}

Received: 15 September 2009 / Accepted: 30 November 2009/Published online: 15 December 2009

(C) Springer-Verlag 2009

\begin{abstract}
Nondestructive analyses of medieval reverse paintings on glass revealed the same dyes and pigments customarily used in panel paintings. However, there is one exception: the black colorant is not a carbon-based pigment, but black enamel. In this respect, the stylistic as well as the technical influence of stained glass artwork can clearly be seen on reverse paintings on glass. However, there is a crucial difference: in reverse paintings, the black enamel is not fired onto the glass but painted (cold painting). Additional analyses confirmed these findings. Based on these results, the art form "reverse painting on glass" has technically to be characterized as a mixture of "stained glass" and "panel painting" that nonetheless develops into a genre of its own.
\end{abstract}

Keywords Reverse paintings on glass $\cdot$ Stained glass $\cdot$ Panel paintings · Middle ages $\cdot$ X-ray fluorescence spectroscopy VIS spectroscopy

\section{Introduction}

As an intermediary genre between panel painting and stained glass, reverse painting on glass is an art form that

\section{O. Hahn $(\varangle) \cdot$ T. Wolff}

BAM Bundesanstalt für Materialforschung und -prüfung,

Unter den Eichen 44-46,

12203 Berlin, Germany

e-mail: oliver.hahn@bam.de

S. Bretz $\cdot$ H.-J. Ranz

revertro, Munich, Germany

C. Hagnau

Museum Schnütgen,

Cäcilienstrasse 29,

50667 Cologne, Germany has not received its due appreciation in art history. In the art-historical context long subsumed under the term stained glass, it was not clearly regarded as an independent genre. Many objects from the Middle Ages demonstrate an elaborate production technique. In the last decades, research followed by several exhibitions highlighted the acceptance of "Hinterglasmalerei" - the German term for reverse paintings on glass - and corrected mistaken ideas concerning their technology.

The European tradition of painting on the reverse side of a piece of glass, and intending that the decoration be viewed from the glass side, has a long history. The art of applying colors to the reverse side of a piece of glass originated in Antiquity (Keiser 1937; Dreier 1961; Ryser 1992). This technique, which had survived in the Byzantine Empire since Late Antiquity, is found in thirteenth century Italy. Initially, small-format panels, painted from the reverse side and backed with gold, were worked as inlays into segments of architecture and into liturgical apparatus. Since the fifteenth century, well into the sixteenth century, devotional and decorative objects like house altars, reliquaries, and kissing paxes were produced in the southern and northern European countries. Stylistic changes were made to suit Baroque and Rococo tastes, and more color appeared in reverse paintings now. Decoration enriched with gold engravings appeared on magnificent room installations, furniture, mirrors, wall-hanging pictures, and beakers. In the nineteenth century, it became popular as folk art. Due to decreasing quality, reverse paintings of glass lost significance at that time.

Our interdisciplinary research has focused on reverse paintings on glass in Germany, Flanders, and Burgundy in the period between 1330 and 1550. Paintings of this kind were highly valued in the Middle Ages and were commissioned by the Church, ruling houses, and the high nobility. The reflections on the surface of the glass helped to create a 
sense of mystery. Over these two centuries, reverse paintings had changed from decoration applied mainly to devotional objects into an independent artistic expression. The technique was demanding for an artist, as the work had to be visualized in its entirety before it began. The painter started by applying the highlights and the final detail of the image, progressing by moving backward in layers of paint, creating the larger areas of the design, and ending with the background (Bretz 2003). The technique used for reverse painted glass in the countries north of the Alps is close to stained glass. Glass is the substrate material in both cases; in reverse paintings, the glass is decorated with pigments in organic binding media (so-called cold painting), while stained glass is decorated with enamels that are fired onto the glass. The crucial difference is revealed in the role of light: reverse paintings on glass are viewed solely with the light falling onto them in reflected light. Such framed pictures are always painted from the front to the back, because the glass surface is the side exposed to view. Stained glass, by contrast, has its particular effect by virtue of its transparence and light falling through it (transmitted light-Ryser 1992; Salmen 1997; Jolidon 1999; Bretz 1999).

For the late medieval glass paintings, as a first layer, black contours were drawn with a pointed brush onto the glass, and a variety of techniques from brushwork to partially crosshatching with a pinfeather or needle were used for shading (Fig. 1). Oil-based paint was applied afterwards in different colors and shades. For creating more sparkle and luminosity, colorful translucent lacquers were also used and backed with metal foil (gold, silver, or tin) - a technique known as verre eglomise, after Jean-Baptiste Glomy, the artist who popularized the technique (Bretz 1999).

\section{Investigated works of art}

Our study focused on reverse paintings on glass in Germany, Flanders, and Burgundy in a period of time between 1330 and 1550. All in all, about 50 objects were investigated. Table 1 summarizes the most important objects of our study. All investigations were carried out by nondestructive methods, which means digital image analysis, visible reflectance spectroscopy (VIS), and X-ray fluorescence analysis (XRF).

\section{Experimental methods}

Digital image analysis

The advantage of reverse painted glass is the visual examination of both sides: glass side as well as painted side. The visual microanalysis of painting techniques was obtained by

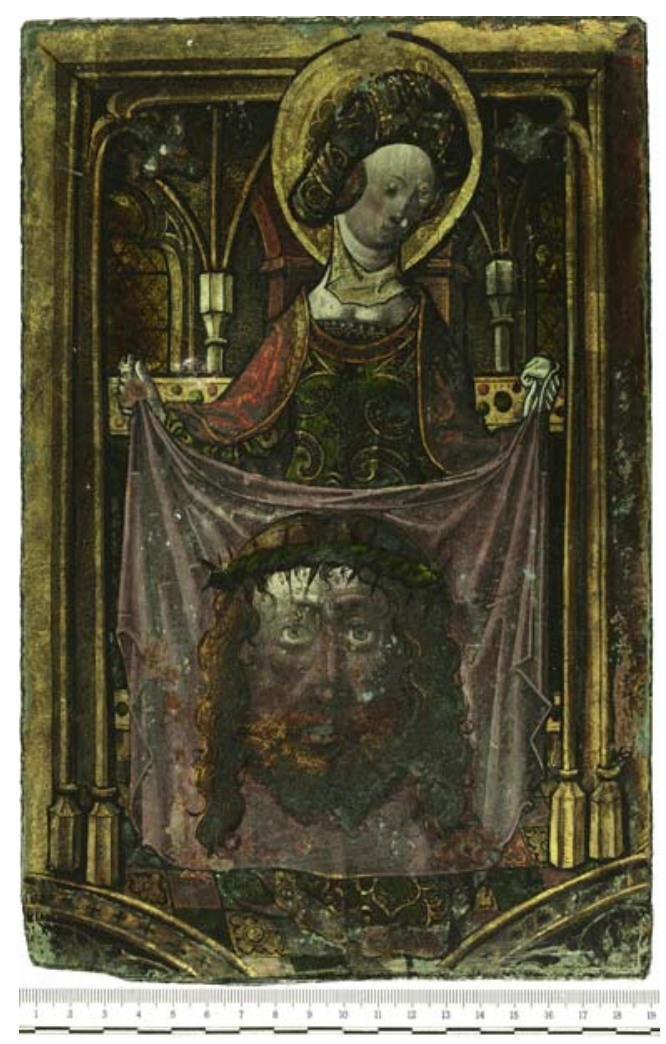

Fig. 1 St. Veronica, Museum Schnütgen, Cologne, Inv.-No.: M172, about 1450

examination under varying incidences of light (transmitted light, reflected light, grazing incidence of light). A specially constructed photo table was used for the digital photographic analysis of the objects. The analyses were carried out with an Olympus BX 41 light microscope, and for the image analyses, we used a special digital closure part (type M11, Jenoptik). It was possible to study specific painting techniques as well as characteristic alteration phenomena.

\section{VIS reflectance spectroscopy}

A convenient technique for the nondestructive investigation of colored materials is the use of visible reflectance spectroscopy (Leona and Winter 2001; Dupuis et al. 2002; Bacci et al. 2009). In our study, we investigated dyes using the color spectrometer SPM 100 (Gretag-Imaging AG, Regensdorf, Switzerland), which measures the reflection of visible light (from 380 to $730 \mathrm{~nm}$, spectral resolution $10 \mathrm{~nm}$ ). It facilitates the measurement of a small spot of about $4 \mathrm{~mm}$ diameter. During the measuring process, the surface of the sample is illuminated for half a second, using a small 2-W bulb. The characteristic reflectance spectrum is measured and recorded (Hahn et al. 2004). By comparing this specific spectrum with a database, it is possible to identify most of the colored materials - organic as well as 
Table 1 Investigated objects (selection)

\begin{tabular}{|c|c|c|c|c|c|}
\hline & Object & Collection & Provenance & Dating & $\begin{array}{l}\text { Detection of black } \\
\text { enamel }\end{array}$ \\
\hline \multirow[t]{3}{*}{ 14th ct. } & $\begin{array}{l}\text { Wooden casket with reverse } \\
\text { glass paintings }\end{array}$ & $\begin{array}{l}\text { Bavarian National Museum, } \\
\text { Munich }\end{array}$ & Northern Germany & About 1330 & Microscopy \\
\hline & Meditation Panel & National Museum, Schwerin & Lüneburg & About $1330-1340$ & Microscopy, XRF \\
\hline & $\begin{array}{l}\text { Fragment of an altarpiece, } \\
\text { showing two apostles }\end{array}$ & National Museum, Schwerin & Lüneburg & About $1330-1340$ & Microscopy \\
\hline \multirow[t]{10}{*}{15 th ct. } & Adoration of the Magi & $\begin{array}{l}\text { Suermondt-Ludwig-Museum, } \\
\text { Aachen }\end{array}$ & Rhenish, Cologne? & $\begin{array}{l}\text { After } 1450 \text {, before } \\
1500\end{array}$ & Microscopy, XRF \\
\hline & Christ mocked & $\begin{array}{l}\text { Bavarian National Museum, } \\
\text { Munich }\end{array}$ & $\begin{array}{l}\text { Flemish or Middle } \\
\text { Rhine }\end{array}$ & $\begin{array}{l}\text { Beginning of } \\
15 \text { th ct. }\end{array}$ & Microscopy, XRF \\
\hline & Maria Lactans & $\begin{array}{l}\text { Museo Civico d'Arte Antica, } \\
\text { Turin }\end{array}$ & French? & About 1400 & Microscopy \\
\hline & $\begin{array}{l}\text { St. John the Baptist and } \\
\text { St. Antony }\end{array}$ & $\begin{array}{l}\text { Museo Civico d'Arte Antica, } \\
\text { Turin }\end{array}$ & Burgundy? & About $1430-1350$ & Microscopy \\
\hline & Death of St. Mary & $\begin{array}{l}\text { Museo Civico d'Arte Antica, } \\
\text { Turin }\end{array}$ & German & About $1450-1500$ & Microscopy \\
\hline & Madonna and Child & $\begin{array}{l}\text { Museo Civico d'Arte Antica, } \\
\text { Turin }\end{array}$ & Flemish & After 1470 & Microscopy \\
\hline & The Nativity & $\begin{array}{l}\text { Museo Civico d'Arte Antica, } \\
\text { Turin }\end{array}$ & German & $\begin{array}{l}\text { Second half } \\
15 \text { th ct. }\end{array}$ & Microscopy \\
\hline & Wedding of St. Catherine & $\begin{array}{l}\text { Museo Civico d'Arte Antica, } \\
\text { Turin }\end{array}$ & German? & $\begin{array}{l}\text { Second half } \\
15 \text { th ct. }\end{array}$ & Microscopy \\
\hline & The Nativity & $\begin{array}{l}\text { Museo Civico d'Arte Antica, } \\
\text { Turin }\end{array}$ & Flemish & $1425-1450$ & Microscopy \\
\hline & Madonna with Mandorla & $\begin{array}{l}\text { Museum of Decorative Arts, } \\
\text { Berlin }\end{array}$ & $\begin{array}{l}\text { Lower Rhine or } \\
\text { Dutch }\end{array}$ & About 1500 & Microscopy \\
\hline \multirow[t]{15}{*}{ 16th ct. } & St. Paul with benefactress & $\begin{array}{l}\text { Museo Civico d'Arte Antica, } \\
\text { Turin }\end{array}$ & French & $\begin{array}{l}\text { Beginning of } \\
\text { 16th ct. }\end{array}$ & Microscopy \\
\hline & St. Magdalena & $\begin{array}{l}\text { Museum of Decorative Arts, } \\
\text { Berlin }\end{array}$ & Dutch & First half 16 th ct. & Microscopy, XRF \\
\hline & St. Veronica & Museum Schnütgen, Cologne & $\begin{array}{l}\text { Flemish or } \\
\text { Cologne }\end{array}$ & $\begin{array}{l}\text { After } 1420 ? / \text { before } \\
1520 ?\end{array}$ & Microscopy, XRF \\
\hline & Annunciation & $\begin{array}{l}\text { Suermondt-Ludwig-Museum, } \\
\text { Aachen }\end{array}$ & $\begin{array}{l}\text { Southern } \\
\text { Germany }\end{array}$ & After 1513 & Microscopy, XRF \\
\hline & St. Catherine of Alexandria & Vitromusée, Romont & Dutch & 1523 & Microscopy, XRF \\
\hline & St. Anne with benefactress & Vitromusée, Romont & Dutch & First half 16 th ct. & Microscopy, XRF \\
\hline & Adoration of the Magi & $\begin{array}{l}\text { Museo Civico d'Arte Antica, } \\
\text { Turin }\end{array}$ & German & First half 16 th ct. & Microscopy \\
\hline & Madonna and Child & $\begin{array}{l}\text { Museo Civico d'Arte Antica, } \\
\text { Turin }\end{array}$ & German & 1533 & Microscopy \\
\hline & Altar of St. Theodosia & $\begin{array}{l}\text { Museum Catharijne- convent, } \\
\text { Utrecht }\end{array}$ & Dutch & 1545 & Microscopy, XRF \\
\hline & Triumph of Christ & $\begin{array}{l}\text { Museum Catharijne-convent, } \\
\text { Utrecht }\end{array}$ & Dutch & 1556 & Microscopy \\
\hline & Annunciation & $\begin{array}{l}\text { Suermondt-Ludwig-Museum, } \\
\text { Aachen }\end{array}$ & German & After 1513 & Microscopy, XRF \\
\hline & Salome & Rijksmuseum, Amsterdam & Dutch & 1510 & Microscopy \\
\hline & Trinity & Rijksmuseum Amsterdam, & Dutch & After 1550 & Microscopy \\
\hline & The Last Supper & Historical Museum, Bern & Peter Balduin, Zofingen & 1589 & Microscopy, XRF \\
\hline & Madonna and Child & $\begin{array}{l}\text { Museo Civico d'Arte Antica, } \\
\text { Turin }\end{array}$ & Flemish & First half 16 th ct. & Microscopy \\
\hline
\end{tabular}

inorganic. The database is located at the BAM, and it was created by use of reference materials. It is not possible to analyze achromatic materials such as black or white pigments.
X-ray fluorescence analysis

The analyses were carried out with the mobile energydispersive micro-X-ray spectrometer ArtTAX ${ }^{\circledR}$ (Bruker axs, 
formerly Röntec-GmbH, Berlin, Germany), which consists of an air-cooled, low-power X-ray tube, polycapillary X-ray optics (measuring spot size $70 \mu \mathrm{m}$ diameter), an electrothermally cooled Xflash detector and a CCD camera for sample positioning.

Furthermore, open helium purging in the excitation and detection paths enables the determination of light elements $(11<Z<20)$ without vacuum. The silicon drift detector with high-speed, low-noise electronics permits an energy resolution of $160 \mathrm{eV}$ for $\mathrm{Mn} \mathrm{K}_{\alpha}$ radiation at a count rate of $10 \mathrm{kcps}$. It has an active area of $5 \mathrm{~mm}^{2}$ and an $8-\mu \mathrm{m}$ thick Dura-beryllium window. The geometry between primary beam, sample, and detector is fixed at $0^{\circ} / 40^{\circ}$ relative to the perpendicular of the sample surface. All measurements are made using a $30-\mathrm{W}$ low-power molybdenum tube, $50 \mathrm{kV}$, $600 \mu \mathrm{A}$, and with an acquisition time of $25 \mathrm{~s}$ (live time) to minimize the risk of damage. In glass, matrix detection limits (DLs) for elements with $z>19$ : DLs are less than $100 \mathrm{ppm}$. For elements with $11<z<18$ : DLs range from $5 \%$ to $1 \%$. For better statistics, at least ten single measurements were averaged for one data point (Hahn et al. 2005).

\section{Results of different analyses}

At first, the nondestructive analyses by VIS and XRF of the late medieval reverse paintings on glass from the fourteenth to sixteenth century revealed dyes and pigments customarily used in panel paintings at this time (Harley 1982). They range from mineral pigments, like various ochres and azurites, through artificial pigments, like lead white and lead-tin yellow, to numerous organic dyes (see Table 2, Haff 1999). The pigments were identified on the basis of their inorganic compounds. All colored materials could be determined by their characteristic reflectance spectra (Fig. 2). Beyond that, many reverse painted glass objects are decorated with metal foils behind transparent luster paints, which are also found on altar panels at this time. Examples include the Ortenberg Altar and the Bartholomew Altar, which will be discussed more below. Gas chromatography has shown that linseed oil was used as a binder on selected reverse painting glass objects (Bretz et al. 2009).

In addition, micro-XRF revealed the presence of iron $(\mathrm{Fe})$, copper $(\mathrm{Cu})$, and lead $(\mathrm{Pb})$ in the black contourings. Figure 3 shows net-peak intensities of different elements, normalized to 1 . The line scan starts in the glass region basically revealing calcium $(\mathrm{Ca})$ and silicon $(\mathrm{Si})$. The black contour is characterized by the presence of $\mathrm{Fe}, \mathrm{Cu}$, and $\mathrm{Pb}$. At the end of the line scan, the glass mainly contains $\mathrm{CaO}$ and $\mathrm{SiO}_{2}$.

This is the analytic proof that the black lines and shading were not carried out with a carbon-based pigment but with black enamel. Black enamel consists primarily of coloring iron oxides and a flux, lead glass that already begins to melt at a low temperature, so that the liquefied paint is adhered indissolubly with the pre-softened glass carrier (Weiß 1988; Müller et al. 1997). It is assumed that due to absorption effects, the presence of silicon is not very visible in the lead glass matrix.

The microscopic analysis of this black paint produced another crucial result: the damage indicates that the investigated objects were cold-painted. The detailed view shown from "Christ Mocked" (Bavarian National Museum, Munich, Fig. 4) makes it clear that the black layer of paint has flaked off from the surface of the glass without remnants (Schott 1999). The aging phenomena are even more impressive when viewed under polarized light. The Newton's rings document the phenomenon of delamination between the glass and the black paint that would not be visible if fired (Fig. 5). Furthermore, quantified XRF spectra prove unequivocally that the black enamel painting was not fired. Table 3 shows the absolute quantification of black enamel

Table 2 Investigated colorants and metals

\begin{tabular}{|c|c|c|}
\hline Color & Pigments and dyes & Investigation techniques \\
\hline \multirow[t]{2}{*}{ Red } & cinnabar $[\mathrm{HgS}]$, red lead $\left[\mathrm{Pb}_{3} \mathrm{O}_{4}\right]$, red ochre $\left[\mathrm{Fe}_{2} \mathrm{O}_{3}\right]$ & XRF, VIS \\
\hline & brazilwood (Caesalpinia brasiliensis L), carmine (e.g., cochineal), lichen dye (e.g., orchil) & VIS \\
\hline \multirow[t]{2}{*}{ Yellow } & $\begin{array}{l}\text { yellow ochre }[\alpha-\mathrm{FeO}(\mathrm{OH})] \\
\text { lead-tin yellow, e.g., }\left[\mathrm{Pb}_{2} \mathrm{SnO}_{4}\right]\end{array}$ & XRF, VIS \\
\hline & common buckthorn (e.g., Rhamnus spp.) & VIS \\
\hline \multirow[t]{2}{*}{ Blue } & azurite $\left[2 \mathrm{CuCO}_{3} \times \mathrm{Cu}(\mathrm{OH})_{2}\right]$, smalt (Co-glass) & XRF, VIS \\
\hline & indigo (eg. Isatis tinctoria L.). & VIS \\
\hline Green & $\begin{array}{l}\text { copper green pigment } \\
\left.\text { (e.g., malachite }\left[\mathrm{CuCO}_{3} \times \mathrm{Cu}(\mathrm{OH})_{2}\right]\right)\end{array}$ & XRF \\
\hline White & lead white $\left[2 \mathrm{PbCO}_{3} \times \mathrm{Pb}(\mathrm{OH})_{2}\right]$, chalk, calcite $\left[\mathrm{CaCO}_{3}\right]$ & $\mathrm{XRF}$ \\
\hline Black & black enamel ( $\mathrm{Pb}$-glass containing $\mathrm{Fe}-/ \mathrm{Cu}-\mathrm{oxides})$ & $\mathrm{XRF}$ \\
\hline Metals & gold $(\mathrm{Au})$, silver $(\mathrm{Ag})$, tin $(\mathrm{Sn})$, brass $(\mathrm{Cu} / \mathrm{Zn})$, zwischgold leaf $(\mathrm{Au} / \mathrm{Ag})$ & $\mathrm{XRF}$ \\
\hline
\end{tabular}




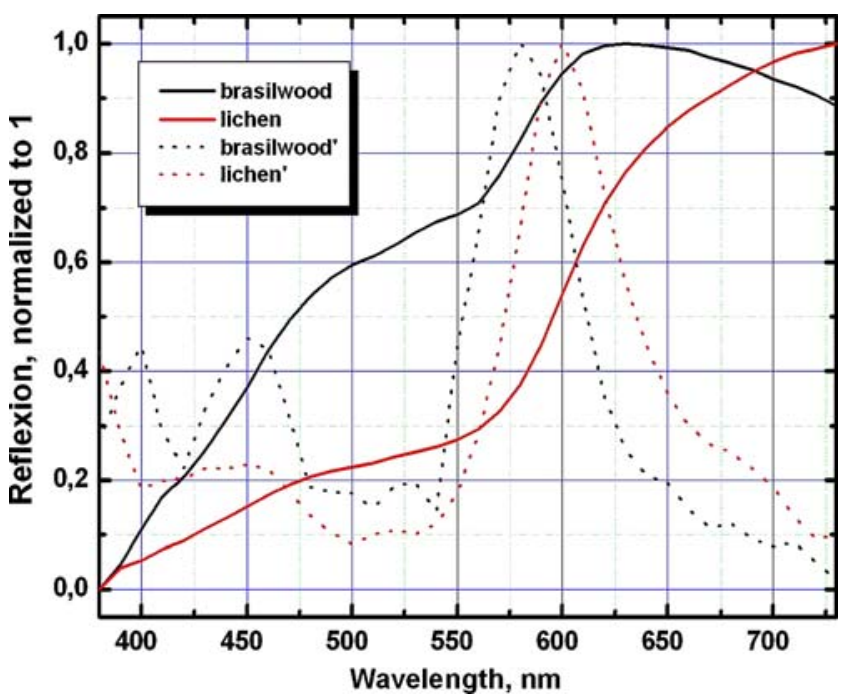

Fig. 2 Representative VIS spectra of two red dyes: brazilwood and one lichen dye. Additionally, the first derivatives (') are plotted in the diagram (for better comparability, the intensities of the spectra, as well as the derivatives, are normalized to 1 )

samples from reverse painting glass objects as well as one fired black enamel sample from stained glass (St. Philippus). The quantitative analysis was done using the so-called fundamental parameter approach (Kanngießer 2003). This quantification procedure is based on a set of equations mathematically describing the fluorescence production and detection (Sherman 1955; Shiraiwa and Fujino 1966). The cross-sections for the interaction of X-rays with matter can be taken from databases (Elam et al. 2002). The element concentrations can be determined in an iteration process.

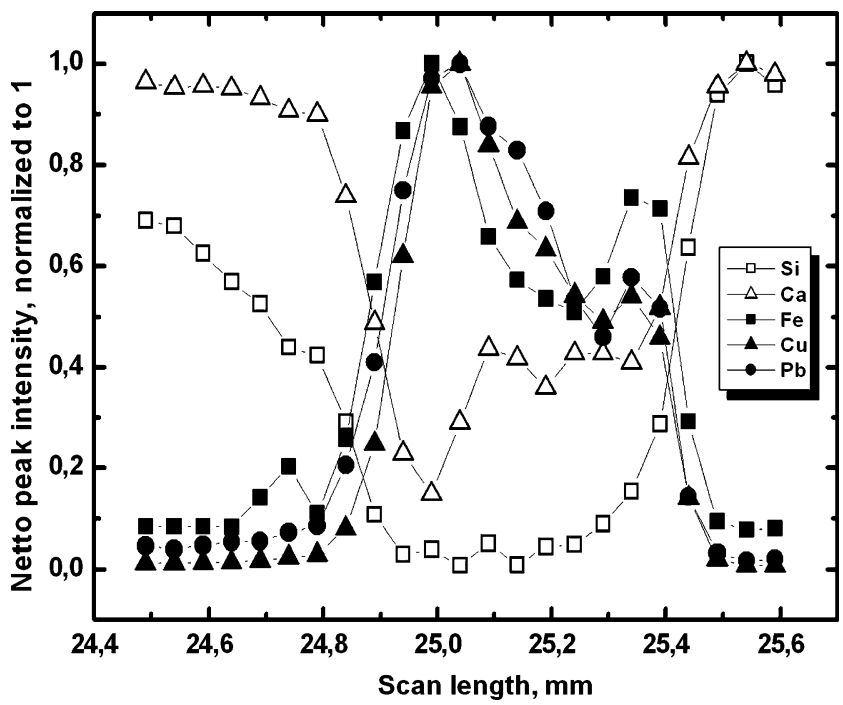

Fig. 3 XRF analysis (line scan) of one black contour. The diagram shows net peak intensities of different elements, normalized to 1 . The line scan starts in the glass region, basically revealing calcium $(\mathrm{Ca})$ and silicon $(\mathrm{Si})$. The black contour is characterized by the presence of iron $(\mathrm{Fe})$, copper $(\mathrm{Cu})$, and lead $(\mathrm{Pb})$. At the end of the line scan, the glass contains $\mathrm{Ca}$ and $\mathrm{Si}$

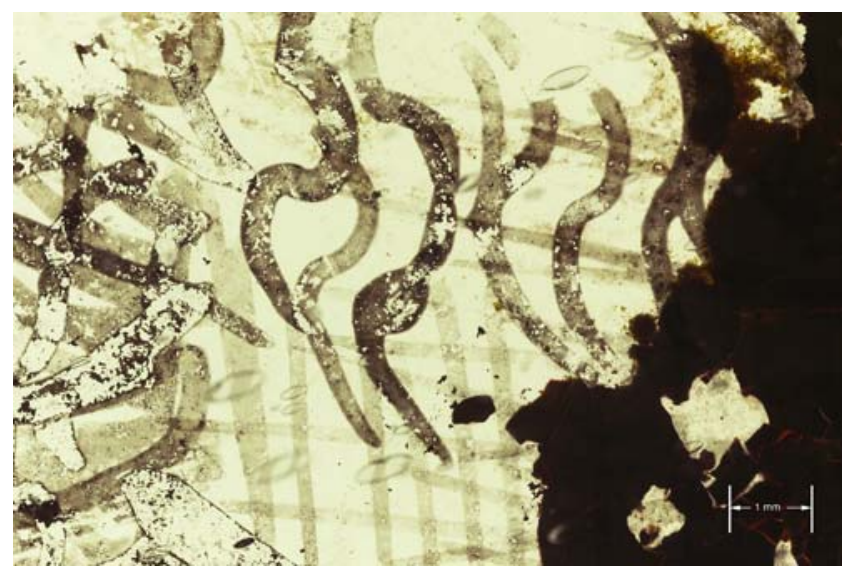

Fig. 4 Christ Mocked (Bavarian National Museum, Munich, Inv. No. $11 / 151$, beginning of the fifteenth century, detail), with a black layer of paint that has flaked off from the surface of the glass without remnant

There is no need to measure reference materials. In addition, the associated glass analyses are represented. The quantification takes into account the thickness of the black contour layer that was obtained by nondestructive three-dimensional
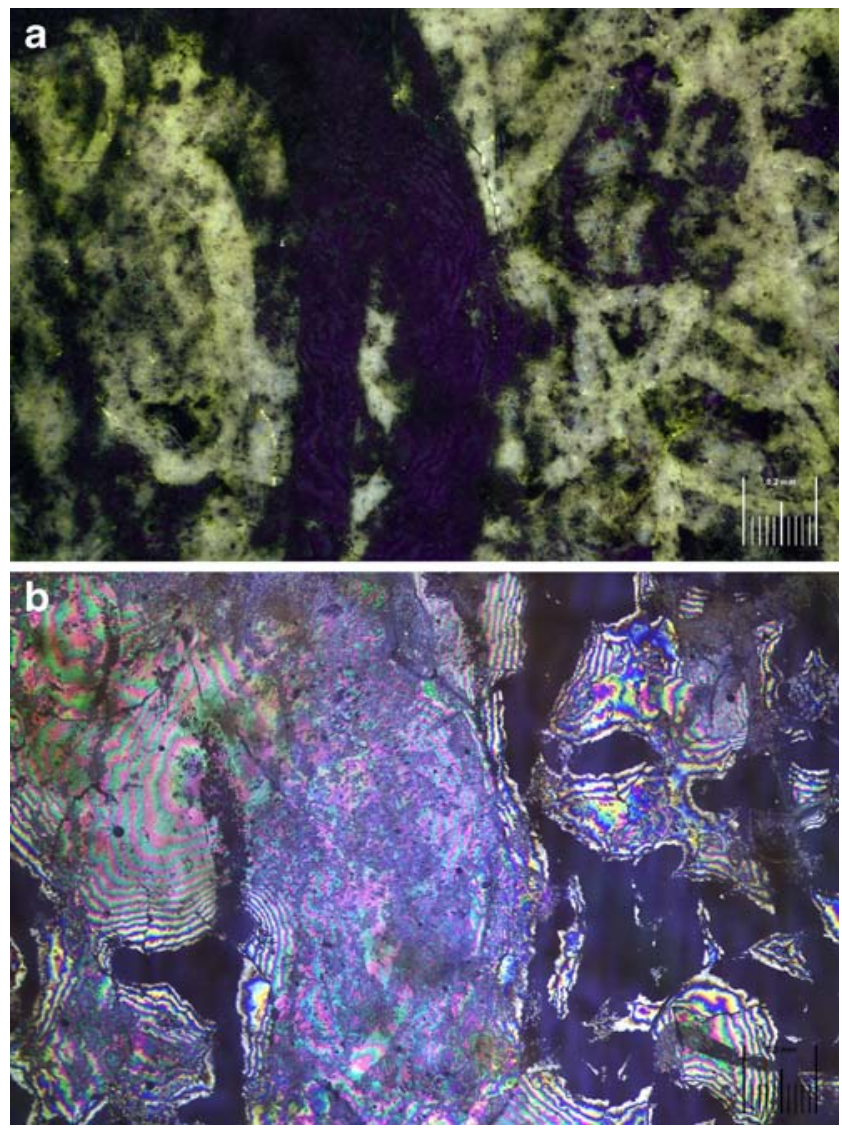

Fig. 5 a upper part St. Veronica (detail), photo micrograph, VIS, dark field illumination, $\times 50$. b Lower part (same detail), photo micrograph, VIS, bright field illumination, $\times 50$. Newton's rings document the phenomena of flaking between the glass and the black paint 


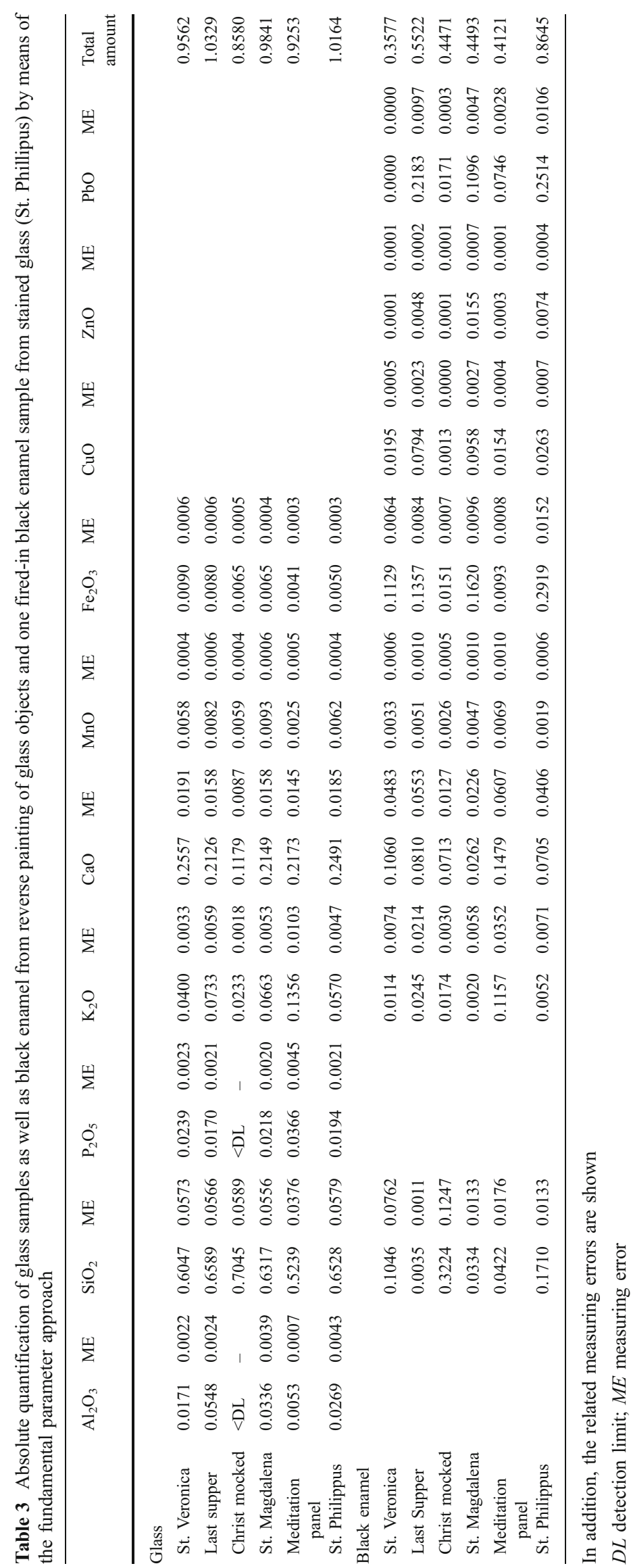


XRF (Mantouvalou et al. 2009). Conspicuous among the non-normalized results is that the total metal oxide content is around $100 \%$ in the fired sample but only about $40 \%$ in the non-fired samples. Taking into account the fact that light elements, for example carbon, are not accessible to analysis by mobile XRF, we assume that the non-fired black enamel samples and the black contours of the corresponding objects contain a certain portion of organic material as a binder that makes the black enamel stick to the glass panel. It would be interesting to determine the binder used for the adhering of the black enamel. However, such determination by nondestructive methods lies beyond the scope of this work.

\section{Discussion and argument}

After the surprising result of the cold-painted black enamel on all investigated late medieval reverse painting glass objects, the question came up why a painting medium from a genre of stained glass found entry to the palette of reverse painting on glass, which usually takes recourse solely to pigments of panel paintings.

For the "Meditation Panel" (Fig. 6) - the earliest piece examined in this study - a pure contour painting in black enamel can be found without the use of any glaze for shading. Schlie (1895) wrote as early as 1895 about the technique of the "Meditation Panel": "... the surface on which the drawing

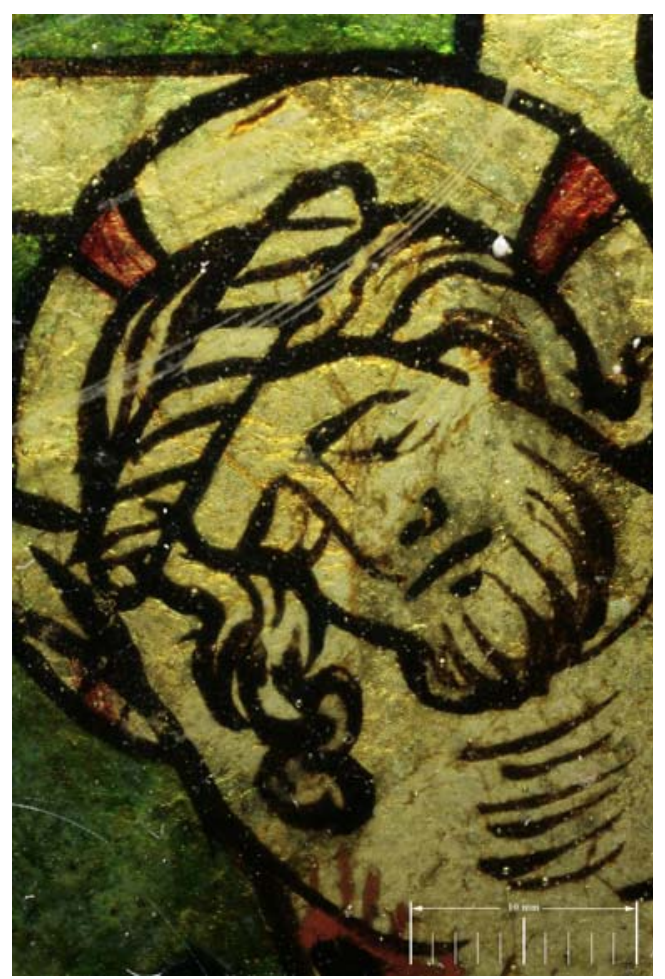

Fig. 6 The Meditation Panel about 1330/40, Public Museum Schwerin, Inv.-No.: G2627 (detail) shows a pure contour painting

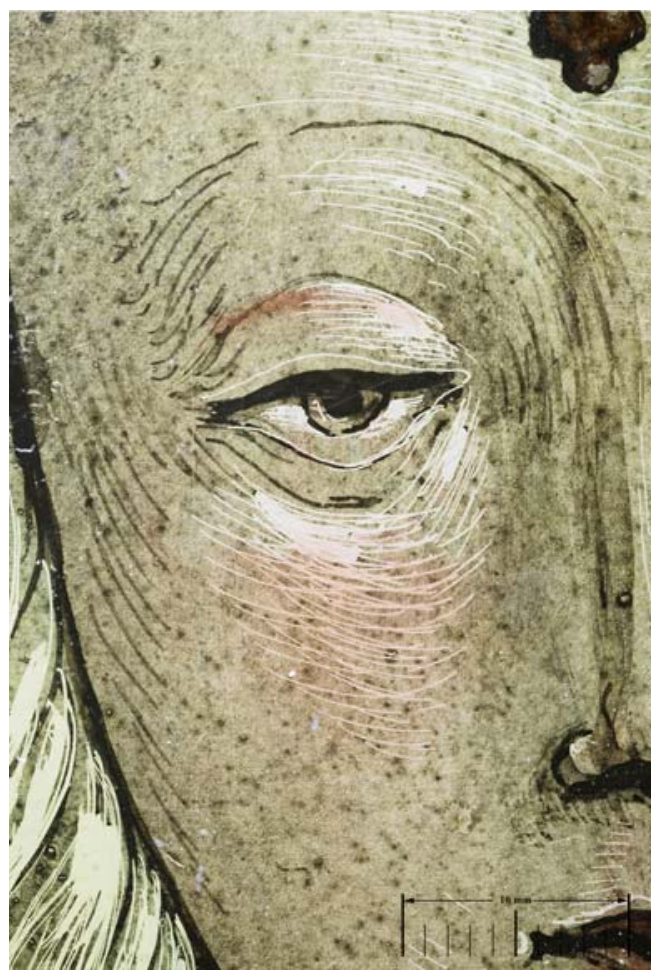

Fig. 7 St. Magdalena (Museum of Decorative Arts, Berlin, Inv. No. F 1861, first half 16th ct., detail) initially shows a contour of black enamel. A thin semi-transparent black glaze was painted onto the contour. Additional modeling was carried out with fine and broad engravings

with black enamel is executed is subsequently gilded, and individual parts of the depiction, for example the garments, are also overlain with a translucent green and red lacquer."

On other glass works painted in reverse that were produced from the mid-fifteenth century onwards, the black paint was technically more elaborate than just contouring or crosshatching. Figure 7-a detail from the "St. Magdalena"initially shows a contour of black enamel. A thin, semitransparent black glaze was then painted onto the contour. Additional modeling was carried out with fine and broad engravings. The contour was in part retraced with an additional application of black enamel.

Such painting or drawing technique can be carried out only with a special, rapidly drying painting medium. Black enamel, a lead glass colored black with iron oxides (and usually containing copper compounds), fulfills this requirement when for example gum is added to it as a binding medium. A pigment like lamp black requires a great amount of binding material and is less suitable for progressing the work of art. The black paint needs to be dry before continuing with the next layer to avoid destroying the underlying work.

After the identification of cold-painted black enamel on reverse paintings on glass, we have to ask whether coldpainted black enamel was also used for the decoration of panel paintings and stained glass. 
Many examples of panel painting have been preserved in which the gilded parts were decorated using fine brushes and deep-black paint (Luckenbach 2002). In this context, Jensen (2007) speaks of black enamel drawing in analogy to stained glass. Examples include the external sides of the "Three Kings Altar" (Cathedral of Cologne), the "Bartholomew Altar" (Wallraf-Richartz Museum, Cologne), the "Altar of the Holy Family", and the "Ortenberg Altar" (Hessian State Museum, Darmstadt). But so far, naturalscientific examinations have turned up evidence only of lamp black pigments, not of black enamel (Kühn 1993; Kühnen 2000; Schäfer et al. 2001). The use of carbon pigments in oil as binding medium in a panel painting is comprehendible. The black contour is the "last" paint layer applied, so a capacity for rapid drying is not essential. Up to now, all these investigations were conducted by taking samples. However, the question of further analyses has to be posed. Carbon-based pigments and black enamels cannot be distinguished by near infrared reflectography, so the only method for nondestructive investigation seems to be X-ray fluorescence analysis.

Analytical results on cold black painting in medieval stained glass artworks seem to be rare. Few references are known. As an example, the Royal Institute for the Study and Conservation of Belgium's Artistic Heritage houses exhibits some thirteenth and fifteenth century stained glass artworks that have passages of black and green cold painting. The analysis of the pigments and binders was carried out with a scanning electron microscope and an infrared spectroscope. However, the black cold painting is not original but considered a repair applied at a later date (Fontaine et al. 1996).

Our result presents a contribution to the discussion whether reverse painting derives from stained glass artwork or panel painting. Reverse painting on glass is first related to stained glass artwork through the painting technique. Both the substrate material glass and black enamel used for contouring, glazing, and engraving come from stained glass. The application of the black paint is, however, different: in the case of stained glass, it is always fired, while in medieval reverse painting on glass, it was always applied cold, as our investigation shows. Starting with pure contour painting in the early pieces (about 1330), it developed into contour together with the application of a glaze that was partially engraved. At the end of the investigated period (about 1550 onwards), the black enamel contour disappeared in favor of pure oil paint.

If the black enamel in reverse painted glass derives from stained glass, all the other materials used for decoration, like oil paint or gold and silver leaf, are derived from panel painting. Thus, we have here an art genre that combines materials and techniques from other genres. Nonetheless, reverse painting on glass can be regarded as an independent art genre due to the challenging technique (painted in reverse) and the general appreciation of splendid artwork.

\section{Conclusion}

Medieval reverse painting on glass is primarily contour painting in black enamel. The beginning of the process of painting resembles stained glass artwork stylistically and in terms of painting technique. The contours are set with deepblack enamel; the modeling is rendered with cross-hatching or glazing that is applied and then partially removed again. In this way, highlights and shadows are set (Fig. 8). Now, however, we find the step from stained glass painting to panel painting: the black enamel is not fired but instead backed with additional opaque paints, transparent luster paints, or metal foils.

This indicates that reverse painting on glass takes the glass substrate and the kind of contour painting from stained glass but the further process of painting from panel painting. This makes reverse painting on glass a mixture of both techniques that nonetheless develops into a genre of its own.

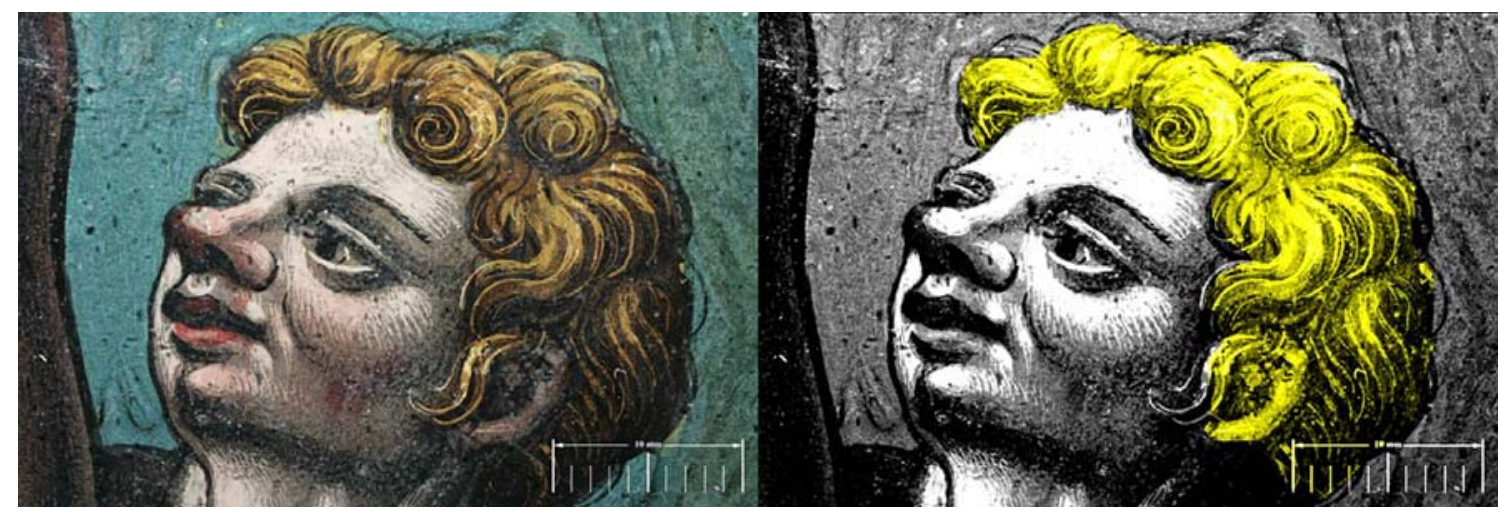

Fig. 8 Trinity (Rijksmuseum Amsterdam, Inv.-No SK-C-1563), detail, as photograph (left) and after digital editing (according to stained glass with black enamel and silver stain, right) 
Precisely in art history, the term "black enamel painting" should no longer be used as a general term for black contour painting in Germany. Where proved that the black paint consists mainly of iron oxide and flux, the term "black enamel painting" is correct and applicable. Since the black enamel was not fired onto the glass in reverse painting, a precise distinction should be made between cold painting with non-fired black enamel and fired black enamel in stained glass.

Acknowledgements The study "Reverse painted glass in Flanders, Burgundy and at the Lower Rhine of 1330 to 1550 . Origins of the 'cold painting' on glass and the influence of stained glass and easel painting" was funded by the Deutsche Forschungsgemeinschaft, code $2728 \mathrm{Ha} / 4-1$. The authors would like to thank Heike Stege, Ursula Baumer, Patrick Dietemann, and Cornelia Tilenschi (Doerner-Institut, Munich) for providing the results of some binder analyses. Many thanks to the visited museums for this project, especially to the Bavarian National Museum, Munich, Germany and the Public Museum in Schwerin, Germany.

\section{References}

Bacci M, Magrini D, Picollo M, Vervat M (2009) A study of the blue colors used by telemaco signorini (1835-1901). J Cult Herit $10: 275-280$

Bretz S (1999) Maltechnik und glastechnik in der hinterglasmalerei 1600-1650, in: Farbige Kostbarkeiten aus Glas, Kabinettstücke der Zürcher Hinterglasmalerei 1600-1650, Munich/Zurich, pp 181-219

Bretz S (2003) Information on the history, technology, deterioration and restoration of reverse paintings on glass. In: Davison S (ed) Conservation and Restoration of Glass. Butterworth-Heinemann, Oxford, pp 54-59, pp 339-433

Bretz S, Baumer U, Stege H, von Miller J, von Kerssenbrock-Krosig D (2009) A German house altar from the sixteenth century: conservation and research of reverse paintings on glass. Stud Conserv 53(4):209-224

Dupuis G, Elias M, Simonot L (2002) Pigment identification by fiberoptics diffuse reflectance spectroscopy. Appl Spectrosc 56 (10): 1329-1336

Dreier FA (1961) Hans Jakob Sprüngli aus Zürich als Hinterglasmaler, In: Zeitschrift für Schweizerische Archäologie und Kunstgeschichte, Schweizerisches Landesmuseum Zürich, Vol. 21, No. 1, Birkhäuser Verlag, Basel, pp 5-18

Elam WT, Ravel BD, Sieber JR (2002) A new atomic database for X-ray spectroscopic calculations. Radiat Phys Chem 63:121-128

Fontaine C, van Bos M, Wouters H (1996) Contribution to the study of cold paint on ancient stained glass windows. In: Dossier de la Comission Royale des Monuments, Sites et Fouilles, Vol. 3 Jaune d'argent, sanguine, email and peinture a froid, pp 85-97

Haff C (1999) Pigmente und Bindemittel der Hinterglasmalerei nach 1600 und deren Analysen. In: Farbige Kostbarkeiten aus Glas, Kabinettstücke der Zürcher Hinterglasmalerei 1600-1650, Munich/Zurich, pp 220-242
Hahn O, Oltrogge D, Bevers H (2004) Colored prints of the 16th century - non destructive analyses on colored engravings from Albrecht Dürer and contemporary artists. Archaeometry 46 (1):273-282

Hahn O, Kanngießer B, Malzer W (2005) X-Ray fluorescence analysis of iron gall inks, pencils, and colored pencils. Stud Conserv 50:23-32

Harley RD (1982) Artists' pigments c. 1600-1835. Archetype, London

Jensen A (2007) Maltechnik und Restaurierung. In: Kreis und Kosmos, ein restauriertes Tafelbild des 15. Jahrhunderts (ed) Kemperdick, S, Kunstmuseum Basel, Imhof Verlag, Petersberg, pp 52-60

Jolidon Y (1999) "Mehr Licht!" Beziehungen zwischen Hinterglasmalerei und Glasmalerei, In: Kunst + Architektur in der Schweiz 50, No. 4, pp 47-55

Kanngießer B (2003) Quantification procedures in micro X-ray fluorescence analysis. Spectrochim Acta, Part B: Atom Spectrosc 58:609-614

Keiser W (1937) Die deutsche Hinterglasmalerei, Munich

Kühn H (1993) Zu Schwarzpigmenten in den Werken Lochners, Technischer Bildaufbau und Farbmittel im Werk Stefan Lochners, In: Ausstellungskatalog Stefan Lochner, Cologne, pp 181-185

Kühnen R (2000) Untersuchungen zur Herstellungstechnik des Altares. In: Vetter EM (ed) Der ortenberger altar. Reichert, Wiesbaden, pp 125-138

Leona M, Winter J (2001) Fiber optics reflectance spectroscopy: a unique tool for the investigation of Japanese paintings. Stud Conserv 46:153-162

Luckenbach C (2002) Die Johannestafel in der Stadtkirche Bad Wimpfen, In: Denkmalpflege in Baden-Württemberg, ISSN 0342-0027, pp 5-12

Mantouvalou I, Wolff T, Lange K, Hahn O, Kanngießer B (2009) 3dimensional X-ray fluorescence analysis of reverse paintings of glass. JAAS, in press

Müller W, Torge M, Kruschke D, Adam K (1997) Sicherung, Konservierung und Restaurierung historischer Glasmalereien, Technical Report 217, ed.: Federal Ministry of Education and Research, code: 515-7291 Bau 5026 G5, Berlin

Ryser F (1992) Reverse paintings on glass, in: the ryser collection, a special exhibition. The Corning Museum of Glass, New York, 1992

Salmen B (1997) Amalierte Stuck uff Glas / Hinder Glas gemalte Historien und Gemäld. In: Hinterglaskunst von der Antike bis zur Neuzeit, Schloßmuseum Murnau, pp 76-95

Schäfer I, Frohnert C, Klinkhammer R, Steinbüchel C (2001) Technologische untersuchung der tafelmalerei des meisters des bartholomäus-altars im kölner wallraf-richartz-museum, in: genie ohne namen-der meisters des bartholomäus-altars. Dumont, Cologne, $177 \mathrm{pp}$

Schlie F (1895) Alterthümer aus Kirche und Kloster des hl. Kreuzes zu Rostock, Zeitschrift für Christliche Kunst, 9, pp 267-282

Schott FL (1999) Die Restaurierung von drei Hinterglasmalereigefässen des Schweizerischen Landesmuseums. In: Farbige Kostbarkeiten aus Glas, Kabinettstücke der Zürcher Hinterglasmalerei 16001650. Munich/Zurich, pp 243-266

Sherman J (1955) The theoretical derivation of fluorescent X-ray intensities from mixtures, Spectrochim. Acta 7:283-306

Shiraiwa T, Fujino N (1966) Theoretical calculation of fluorescent $\mathrm{x}$-ray intensities in fluorescent $\mathrm{x}$-ray, spectrochemical analysis. Jpn J Appl Phys 5:886-892

Weiß G (1988) Glas. In: Reclams Handbuch der künstlerischen Techniken, 2nd ed., Stuttgart pp 55-56 